OPEN ACCESS

Edited by:

Christos Mammides,

Frederick University, Cyprus

Reviewed by:

Caroline Ward,

University of York, United Kingdom

Panayiotis G. Dimitrakopoulos,

University of the Aegean, Greece

*Correspondence:

Naira Dehmel

naira.dehmel@kcl.ac.uk

Phil Franks

phil.franks@iied.org

Specialty section:

This article was submitted to

Forest Disturbance,

a section of the journal

Frontiers in Forests and Global

Change

Received: 01 November 2021

Accepted: 26 January 2022

Published: 18 February 2022

Citation:

Dehmel N, Franks $P$

Schreckenberg K, Beresford A,

Buchanan G and Dawson TP (2022) Relating Country-Level Governance and Tree Cover Loss in Sub-Saharan African Protected Areas: Identifying Knowledge Gaps and a More

Nuanced Perspective.

Front. For. Glob. Change 5:807214. doi: 10.3389/ffgc.2022.807214

\section{Relating Country-Level Governance and Tree Cover Loss in Sub-Saharan African Protected Areas: Identifying Knowledge Gaps and a More Nuanced Perspective}

\author{
Naira Dehmel'1*, Phil Franks' ${ }^{2 *}$ Kate Schreckenberg ${ }^{1}$, Alison Beresford $^{3}$, \\ Graeme Buchanan ${ }^{3}$ and Terence P. Dawson ${ }^{1}$ \\ ${ }^{1}$ Department of Geography, King's College London, London, United Kingdom, ${ }^{2}$ Natural Resources Group, International \\ Institute for Environment and Development, Edinburgh, United Kingdom, ${ }^{3}$ RSPB Centre for Conservation Science, Royal \\ Society for the Protection of Birds, Scotland Headquarters, Edinburgh, United Kingdom
}

'Good governance' is highlighted by many as being essential for improving protected area (PA) management and conservation outcomes, with a growing body of evidence based on site-level governance data. Yet how exactly governance at other levels supports or hinders successful PA implementation, and how this should be considered in conservation planning and practice, remains insufficiently understood. We conducted an exploratory analysis of the relationship between the quality of country-level governance and trends in tree cover loss within sub-Saharan African PAs. For the period 2008-2017, we correlated annual governance scores from the Ibrahim Index of African Governance (IIAG) with the annual rate of tree cover loss in the total terrestrial area of PAs in 33 forested sub-Saharan African countries. Overall governance was not correlated with tree cover loss in a simple model, but there was evidence that overall governance was positively correlated with tree cover loss in PAs when the interaction with environmental governance was included. The interaction indicated that the rate of tree cover loss decreased for a given level of overall governance as environmental governance increased. Human development was negatively correlated with forest loss. Thus, the relationship between country-level 'good governance' and conservation success is more complex than a direct and positive cause and effect. Yet, uncertainty remains about the many possible and likely confounding pathways: whilst the quality of overall governance may be mirrored at the site-level, it may also contribute to increased anthropogenic pressures on natural resources. Through this research we found significant limitations in data quality and availability both to evaluate the effectiveness of protection beyond tree cover, as well as less conventional governance aspects, such as environmental policy and regulation or site-level governance. With an expected increase in area-based protection and conservation financing in the coming decades, such data will be vital to monitor the effectiveness of our efforts and ensure financial accountability.

Keywords: quality of governance, forest protection, protected areas, environmental governance, Ibrahim Index of African Governance 


\section{INTRODUCTION}

The rate of forest loss is greater in Africa than anywhere else in the world (Food and Agriculture Organization [FAO], 2020b; Wolf et al., 2021). From 2010 to 2020, the African continent experienced a net forest loss of 3.9 million ha per year - compared to 2.6 in South America, 0.1 in North and Central America and a slight increase in forest cover in Asia, Europe and Oceania (Food and Agriculture Organization [FAO], 2020b). With economic development expected to recover after the Covid-19 recession in 2020 (AfDB, 2021) and projections of continued population growth (United Nations, 2015), these rates of forest loss will likely continue. Protected Areas (PAs) are one instrument to protect forests as vital biodiversity habitats, global carbon stocks and providers of various ecosystem services (Miller and Nakamura, 2018; Wade et al., 2020; Wolf et al., 2021). At present, the international community is negotiating the new Global Biodiversity Framework for the timespan through to 2030 (Secretariat of the United Nations Convention on Biological Diversity [CBD], 2021). Prominent in the current draft is the so-called ' 30 by 30 ' target to increase the global network of PAs and other effective area-based conservation measures to $30 \%$ of the world's terrestrial and marine surface by 2030 (ibid).

Yet, an increasing number of studies conducted toward the end of the previous Global Biodiversity Framework found inconclusive results relating to the effectiveness of PAs at protecting habitats and biodiversity (Maxwell et al., 2020; Wade et al., 2020; Bolam et al., 2021; Wolf et al., 2021), highlighting that formal designation of PAs is not sufficient to reach their conservation goals. For conservation to be successful, PAs require adequate governance structures, wellestablished management strategies, support of local communities and effective implementation (Borrini-Feyerabend et al., 2013; Barnes et al., 2017), including adequate resourcing, collaborative expertise and careful management of socio-environmental tradeoffs (Maxwell et al., 2020). With the prospect of the new Global Biodiversity Framework leading to a drastic increase in the number and extent of PAs in Africa and worldwide, we need to understand the contextual and systematic factors that enable and hinder their effectiveness.

The quality of the wider governance environment within which PAs are embedded has increasingly attracted attention as an important contextual factor (e.g., Miller et al., 2015; Barnes et al., 2017; Eklund and Cabeza, 2017; Amano et al., 2018; Geldmann et al., 2019). 'Good governance' at the country level is often seen as an important enabling condition for 'good governance' at the site-level (Barrett et al., 2006; Miller et al., 2015). Yet, there is currently limited empirical evidence to sustain this perspective (Barnes et al., 2017). Alternative narratives suggest a more complex picture recognizing the many other factors that country-level governance can have an influence on, including, e.g., market opportunities, infrastructure development, or foreign direct investment, which can potentially conflict with conservation objectives (Barrett et al., 2006; Byerlee et al., 2014; Ceddia et al., 2014). We still have very limited understanding of the role of country-level governance and how it should be considered in conservation policy, planning and practice.

This paper presents findings from an analysis of the relationship between tree cover loss in sub-Saharan African PAs and country-level governance for the time period 2008-2017. It is structured as follows: In the remaining introduction we briefly expand on why considering the role of country-level governance for the success of forested PAs is of pertinence especially in Africa. We then define how governance has been considered in the context of conservation more generally and establish the theoretical link between country-level governance and PA outcomes. In section "Materials and Methods," we present our data sources and statistical analyses followed by the results of this study in section "Results." Section "Discussion" presents a discussion on the multi-level complexity of the relationship between governance and conservation, the importance of environmental governance and the challenge posed by the lack of relevant and good quality data. This paper presents a high-level analysis and is a first approach to this pertinent question. It presents results from initial analyses and, based on these, highlights potential avenues for future analyses to better understand the role of governance in improving PA conservation outcomes.

\section{Forest Loss in Africa}

Habitat loss is among the greatest pressures on biodiversity. Forest loss is of particular concern as almost $65 \%$ of species assessed for the IUCN Red List occur in this habitat, and logging and wood harvesting is a recognized threat to around a third of these (International Union for Conservation of Nature [IUCN], 2022). While Africa is the region which experienced the highest annual rates of net forest loss in the past decade (Food and Agriculture Organization [FAO], 2020b, p. XII), it is also amongst the regions where forests are supposedly protected the most: As of 2020, 27\% of forests in Africa are within legally established PAs (only exceeded by $31 \%$ in South America) and $24 \%$ of Africa's total forest area is primarily designated for biodiversity conservation, the highest proportion worldwide (ibid:65). Five out of the ten countries and territories with the highest proportion of total forest area designated primarily for biodiversity conservation are from Africa (São Tomé Príncipe, Guinea-Bissau, Cameroon, Zambia and Guinea, all with a proportion of $49 \%$ and above) (ibid).

Yet, Wolf et al. (2021) found that Africa also experienced the highest annual forest loss rates within PAs compared with other continents. Overall, forest loss rates within PAs were lower than in unprotected control areas, however, with a smaller net effect in Africa than in most other regions (only Asia experienced lower PA effectiveness, yet at lower forest loss rates) (ibid:4).

Retention of forests on the African continent is of urgency in the light of extreme and increasing levels of forest loss, yet Wolf et al.'s (2021) results emphasize that the legal designation of forests within PAs is not delivering effective protection. Studying the role of country-level governance as one contextual factor for PA effectiveness seems particularly pertinent in Africa where there is a record of the world-wide lowest performance in 
conventional metrics for 'good governance' such as the World Bank's Worldwide Governance Indicators (Kaufmann et al., 2010; Worldbank, 2019).

\section{Governance in Conservation}

Governance is about how things are done, by whom and in whose interest. It describes all processes of decision-making and implementation across levels and sectors (UNESCAP, 2009; Bevir, 2012) and is thus concerned with the distribution of authority, rights, institutions, power and accountability in the setting of rules and their implementation (Borrini-Feyerabend et al., 2013; Eklund and Cabeza, 2017). Which aspects of governance become important depends on the level and subject of consideration. In the field of conservation, governance scholars have been mostly concerned with governance at the conservation site (Macura et al., 2015; Archibald et al., 2020; Dawson et al., 2021) and at the country-level (Barrett et al., 2006; Miller et al., 2015; Amano et al., 2018; Geldmann et al., 2019).

At the site-level of PAs, a distinction is made between the type and the quality of governance (Borrini-Feyerabend et al., 2013). Site-based governance regimes can be split into four types: governance by government, governance by private individuals and organizations, governance by Indigenous peoples and/or local communities, and shared governance (Dudley, 2008; Borrini-Feyerabend et al., 2013). Which of these is most suitable for achieving ecological and socioeconomic objectives is case- and context-specific (Ferraro et al., 2013; Macura et al., 2015; Archibald et al., 2020; Dawson et al., 2021). Site-based governance quality is not necessarily bound to the governance type and is mostly understood in terms of ecological effectiveness and social equity (Andrade and Rhodes, 2012; Borrini-Feyerabend et al., 2013; Miller and Nakamura, 2018). Various frameworks for effective and equitable governance at conservation sites exist but are typically built on the three dimensions of recognition, procedure and distribution (Sikor et al., 2014; Schreckenberg et al., 2016; Franks et al., 2018; Friedman et al., 2018) and include principles such as legitimacy and voice, direction, and performance, accountability, fairness, and rights (Borrini-Feyerabend et al., 2013; Schreckenberg et al., 2016; Franks et al., 2018). There is general agreement that equitable governance is beneficial toward reaching and sustaining ecological effectiveness, although further empirical work in this area is needed (Andrade and Rhodes, 2012; Friedman et al., 2018; Dawson et al., 2021).

At the country-level, the notion of 'good governance' and 'bad governance' prevails in conservation, as in the fields of international development and international relations, as a concept for how transparently and effectively public institutions handle public affairs and resources (Barrett et al., 2006; Miller et al., 2013, 2015). Conventionally, 'good governance' is comprised of effective control of corruption, transparency, accountability, participation and human rights, rule of law and governance effectiveness, as well as political stability and safety (UNESCAP, 2009; Kaufmann et al., 2010; Mo Ibrahim Foundation, 2018). It is generally assumed that these criteria need to be met at different government levels for public policies, donor funds or development or conservation programs to be effectively and sustainably implemented (Barrett et al., 2006; UNESCAP, 2009; Eklund and Cabeza, 2017).

In this study we consider the relationship between countrylevel governance and conservation outcomes, in terms of tree cover loss, in PAs in sub-Saharan Africa using a cross-country analysis approach based on available global databases. Previous cross-country analyses of this type have either not considered governance (Beresford et al., 2013; Barnes et al., 2016; Geldmann et al., 2018; Wade et al., 2020; Wolf et al., 2021), or considered less comprehensive metrics for country-level governance such as corruption indices as one contextual factor for PA effectiveness amongst many others (Geldmann et al., 2019). Other studies analyzed the role of country-level governance and different aspects thereof in influencing biodiversity loss or pressures and drivers thereof more generally (Ceddia et al., 2013, 2014; Amano et al., 2018; Bradshaw and Di Minin, 2019; Usman Mirza et al., 2020). Some of these studies take a global perspective (Barnes et al., 2016; Amano et al., 2018; Geldmann et al., 2018, 2019; Usman Mirza et al., 2020; Wade et al., 2020; Wolf et al., 2021), while others focus on single continents (Beresford et al., 2013; Ceddia et al., 2013, 2014; Bradshaw and Di Minin, 2019). In this study, we link a complete set of country-level governance indicators with PA conservation outcomes focusing specifically on sub-Saharan African countries. We consider tree cover loss as it can be readily mapped in a consistent way at the continental scale using satellite remote sensing data and include all countries with at least $0.05 \%$ of their total land area covered by trees in 2000 .

The following section summarizes theoretical understandings and frameworks on the conceptual mechanisms for how countrylevel governance can influence PA outcomes.

\section{Linking Country-Level Governance to Protected Area Outcomes}

Early assessments of how conservation was affected by 'bad governance' and corruption (e.g., (Deacon, 1994; McPherson and Nieswiadomy, 2000; Smith et al., 2003) were built on the same causal assumptions that prevailed in international development from the 1970s onward and that eventually culminated in the selectivity and conditionality mechanisms for aid allocation as part of structural adjustment policies in the 1990s (Svensson, 1999; Burnside and Dollar, 2004; Eklund and Cabeza, 2017). Governments with little corruption that also had more efficient, transparent, and accountable bureaucracies were and are generally thought of as more successful in producing and implementing public policy (Barrett et al., 2006; Eklund and Cabeza, 2017; Mo Ibrahim Foundation, 2018). In contrast, systems built on corruption, patronage and underpaid civil servants are understood to lead to leakages in donor and public funding and limited law enforcement, which in turn are understood to increase the risk of policy failure. Barrett et al. (2006, p. 6, 7) call this the 'conventional model' for understanding the role of governance and explain how this can be translated to the field of natural resource governance: "When natural resources become valuable in such a context, officials from top 
to bottom will be coerced, bribed, or lured into overexploiting the valuable species (...). No one within the political system is held responsible for such behavior. Even the injection of foreign aid targeted for conservation is susceptible to these same forces. The result is that resources decline, sometimes precipitously." This illustration of the 'conventional model' demonstrates how governance processes at the national level can trickle down to the PA site-level and negatively affect the functioning of local governance and management regimes.

Barrett et al. (2006), however, criticize this assumption as too simplistic. On the one hand, it ignores nuances in how different elements of 'bad governance' do not need to cause natural resource depletion, but instead could make it more costly; for example, when rent seeking and bribery by public officials increases the costs for logging permits or illegal extraction. On the other hand, 'better' governance at the country-level can enable and drive pressures on natural resources at a more structural level linked to economic, technological and demographic factors, e.g., encouraging infrastructure development, agricultural expansion and wood extraction (Geist and Lambin, 2002; Eklund and Cabeza, 2017).

There are multiple drivers for forest loss, but to expand on how 'good governance' could result in increased tree cover loss in PAs, we consider the primary driver of deforestation in the global tropics, which is expansion of crop and livestock production (Curtis et al., 2018; Food and Agriculture Organization [FAO], 2020b; Wade et al., 2020). One principal strategy to counter this expansion has been to support improvements in the efficiency of production, through public investment in agricultural research and development and irrigation (Byerlee et al., 2014). Studies in South America where agricultural expansion and intensification are taking place on a massive scale in the Amazon Basin suggest that intensification can reduce deforestation, but only where environmental governance is strong (Ceddia et al., 2013, 2014; Byerlee et al., 2014). In contrast, where environmental governance is weak, but general governance is relatively strong and thus encouraging to private sector investment, the opposite is common, i.e., intensification drives further expansion (Ceddia et al., 2014). This highlights the importance of considering the role of environmental governance more specifically for the protection of natural resources and ecosystems, particularly to curb the possible direct and indirect negative impacts of improving governance in general.

Eklund and Cabeza (2017) provide a useful framework structured around drivers, pressures, states, impacts and responses to summarize the many complex and likely countervailing pathways by which the quality of governance, and especially country-level governance, can influence PA conservation outcomes. Greatly simplified, it helps to illustrate the hypotheses underlying our analysis (Figure 1). Consolidated for analytical purposes, the ecological outcomes of a PA site depend on two factors: (1) the quality and effectiveness of how PAs are governed and managed, and (2) the extent and severity of (anthropogenic) environmental pressures which they are exposed to. As discussed above, the quality of country-level governance can in different ways be considered

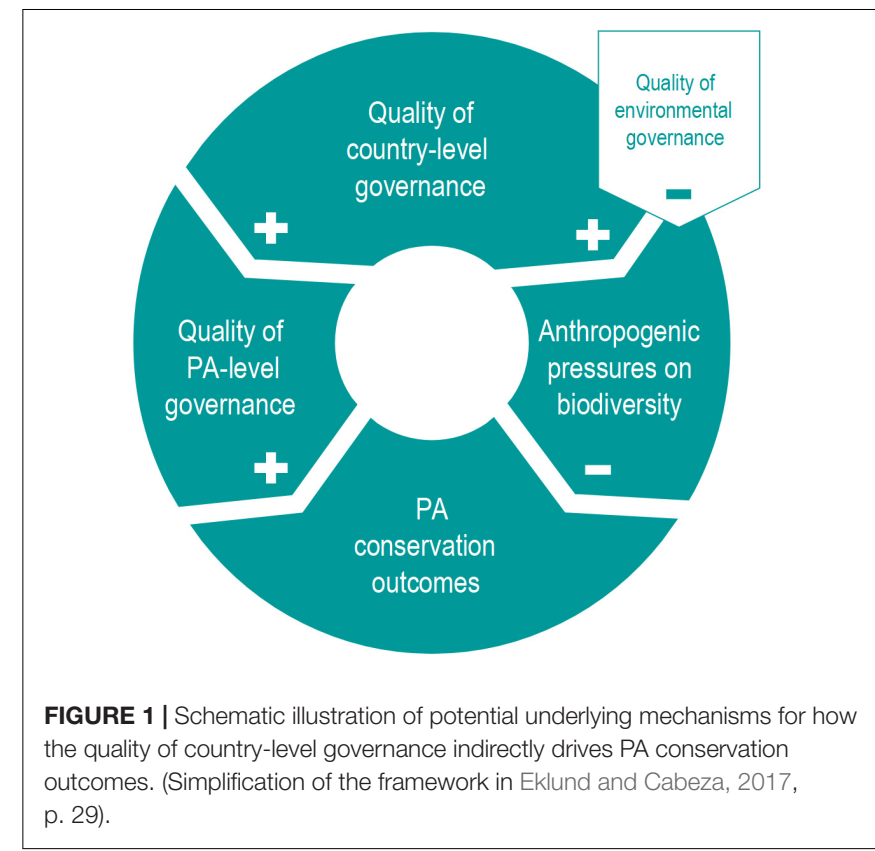

as driving both factors. How the quality of country-level governance in general affects anthropogenic pressures is likely to depend on the quality of environmental governance. We acknowledge the complexity of mechanisms at play but, because of persisting methodological and data challenges, we do not attempt to disentangle all of these. Instead we test whether the quality of country-level governance overall is correlated with tree cover loss in sub-Saharan African PAs.

\section{MATERIALS AND METHODS}

To explore the relationship between the quality of countrylevel governance and the success of forest conservation in PAs, we retrieved time-series data for the period 20082017 from the Ibrahim Index of African Governance (IIAG, version 2018, Mo Ibrahim Foundation, 2018) and the Hansen Global Forest Change dataset (version 1.6 ${ }^{1}$ ). Data on the PAs was taken from the World Database of Protected Areas (WDPA, July 2020 version, UNEP-WCMC, 2019), and control variables included in our analysis from the World Bank's World Development Indicators database (World Bank Group, 2021) $)^{2}$.

The IIAG compiles data from 35 quantitative and qualitative sources in a multidimensional framework for national governance (Mo Ibrahim Foundation, 2018). For the IIAG,

\footnotetext{
${ }^{1}$ https://earthenginepartners.appspot.com/science-2013-global-forest/download_ v1.6.html

${ }^{2}$ We used the following software for data preparation, analysis, and visualization: QGIS (QGIS Development Team, 2021), Google Earth Engine (Gorelick et al., 2017), and RStudio Version 1.4.1106 (RStudio Team, 2021). Used R packages: 'tidyverse' (Wickham et al., 2019), 'plm' (Croissant and Millo, 2008), 'Hmsic' (Harrell and Dupont, 2021), 'ggrepel' (Slowikowski, 2021), 'gridExtra' (Auguie, 2017), and 'stargazer' (Hlavac, 2018).
} 
governance is defined as "the provision of the political, social and economic public goods and services that every citizen has the right to expect from their state, and that a state has the responsibility to deliver to its citizens" (ibid:4). Reflecting this, the index clusters 191 variables at different levels to form four governance categories:

1. Safety and Rule of Law (comprises four sub-categories: Rule of Law, Transparency and Accountability, Personal Safety, National Safety).

2. Participation and Human Rights (comprises three subcategories: Participation, Rights, Gender).

3. Sustainable Economic Opportunity (comprises four subcategories: Public Management, Business Environment, Infrastructure, Rural Sector).

4. Human Development (comprises three sub-categories: Welfare, Education, Health).

These four categories are bundled with equal weighting into one overall governance performance score. The scores for overall governance and the four governance categories are normalized and range from 0 to 100 (ibid). At the time of our analysis, the IIAG was available for all 54 African countries for 20082017 (South Sudan from 2011 to 2017). Missing data over this time series have been imputed to ensure continuity using a range of imputation methods selected through simulation experiments (ibid).

The IIAG includes a score for the quality of environmental policy at the country-level provided by the Bertelsmann Transformation Index. This score is based on expert valuation and rates the extent to which countries are effectively taking into account environmental concerns on a scale from 1 to 10 (Bertelsmann Stiftung, 2020). We use this score as a best available proxy at the time of our analysis for the quality of countries' environmental governance.

It was not possible to include an indicator for site-level governance type or quality in our analysis as too few African PAs have reported their governance type in the WDPA, and we do not know of a sufficiently large database on the quality of sitelevel governance that could be meaningfully considered at our level of analysis.

The Hansen Global Forest Change data map tree cover in 2000 at a resolution of 1 arc second (c. $30 \mathrm{~m}$ at the equator) and provide time-series data of tree cover loss in each pixel until 2018. Other measures of forest conservation effectiveness have been used (e.g., fires in Nelson and Chomitz, 2011). However, we focus on tree cover loss as it captures a wider range of potential drivers of loss. Curtis et al. (2018) found that fires are the drivers of only $27 \%$ of tree cover loss, with the remainder attributed to agriculture (including commodities) and forestry activities. We consider only yearly tree cover loss from the period 2008-2017 to match the IIAG data and define 'tree cover' at the 50\% canopy cover threshold. We recognize that there are multiple definitions of significant tree cover densities, including FAO's forest definition of 10\% canopy cover (Food and Agriculture Organization [FAO], 2020a). Landsat data, however, cannot discern canopy cover at this level (Achard et al., 2014). Therefore, instead, we follow
Hansen et al. (2013) who in their analysis of forest change focus on areas where canopy cover in pixels was above 50\%. We only included the 33 sub-Saharan African countries ${ }^{3}$ in our analysis that had at least $0.05 \%$ tree cover within their national boundaries in 2000 .

Following the approach taken by Beresford et al. (2020), the spatial time-series of tree cover loss were overlayed with the boundaries of terrestrial PAs that are recorded in the WDPA. We included only PAs that had been established, designated, or inscribed by 2008 (excluding proposed sites) and excluded World Heritage Sites and UNESCO MAB Biosphere Reserves to focus on sites for which biodiversity conservation is the primary objective. PAs recorded as points rather than polygons were discarded. In total, this resulted in 5797 PAs across all 33 countries, ranging from a minimum of 1 in Comoros to 1348 in South Africa. Given the large overlap in PA designations in the WDPA and to avoid double counting of spatial coverage, we combined all PAs in each country in one layer. Transboundary PAs were divided along administrative borders. We finally considered annual percentage rates of tree cover loss within all the PAs in a country. Across all our analyses, the percentage rate of tree cover loss was log-transformed for its highly right skewed distribution.

To compare across countries how the level of governance quality at the country-level is associated with tree cover loss in PAs, we first conducted simple linear correlation analyses of the mean scores for governance and tree cover loss rates across the whole time period (Table 1). In a second step, panel linear regressions with country and time fixed effects were used to test how changes in governance within countries relate to tree cover loss in PAs over time (Table 2). We tested these relationships for both the overall IIAG governance score (hereafter 'Overall Governance') and for each of the four categories ('Security and Rule of Law,' 'Participation and Human Rights,' 'Sustainable Economic Opportunity', and 'Human Development'). Separate models were conducted for each governance category to avoid multi-collinearity [models (1)-(5) in Tables 1,2]. In each model, we included the country's gross domestic product (GDP) and population density as control variables, as they have previously been found to significantly correlate with conservation outcomes and are typically included as control variables (Amano et al., 2018; Geldmann et al., 2018, 2019; Wolf et al., 2021) ${ }^{4}$. In the crosscountry analysis we additionally controlled for the differences

\footnotetext{
${ }^{3}$ These countries were included in our study: Angola, Benin, Burundi, Cameroon, Central African Republic, Comoros, Congo, Côte d'Ivoire, Democratic Republic of Congo, Equatorial Guinea, Eswatini, Ethiopia, Gabon, Ghana, Guinea, GuineaBissau, Kenya, Liberia, Madagascar, Malawi, Mauritius, Mozambique, Nigeria, Rwanda, São Tomé Príncipe, Seychelles, Sierra Leone, South Africa, South Sudan, Tanzania, Togo, Uganda, Zambia.

${ }^{4}$ Other variables previously considered in models for PA effectiveness and/or environmental performance overall include geophysical and other characteristic variables at the PA level (elevation, slope, distance to nearest city, PA size, date of establishment, IUCN management category etc.), as well as road density, the Gini index of income inequality and the human development index at the country level (Barnes et al., 2016; Geldmann et al., 2018, 2019; Bradshaw and Di Minin 2019; Usman Mirza et al., 2020; Wolf et al., 2021). As our analysis is conducted at the country-level, the PA level characteristics were not considered. Road density and the human development index were not included as very similar measures are included in the IIAG. The Gini index was not included as it was not available as
} 
TABLE 1 | Summary of parameter estimates (SE) from linear regression of tree cover loss against governance and additional covariates, comparing mean values across countries.

\section{Dependent variable:}

\begin{tabular}{|c|c|c|c|c|c|c|}
\hline & \multicolumn{6}{|c|}{ Mean annual tree cover loss rate in PAs ( $\%$, log transformed) } \\
\hline & (1) & (2) & (3) & (4) & (5) & (6) \\
\hline $\begin{array}{l}\text { Overall } \\
\text { Governance }\end{array}$ & $\begin{array}{l}-0.037 \\
(0.033)\end{array}$ & - & - & - & - & $\begin{array}{l}0.123^{\star *} \\
(0.050)\end{array}$ \\
\hline $\begin{array}{l}\text { Safety and Rule } \\
\text { of Law }\end{array}$ & - & $\begin{array}{l}-0.013 \\
(0.028)\end{array}$ & - & - & - & - \\
\hline $\begin{array}{l}\text { Participation } \\
\text { and Human } \\
\text { Rights }\end{array}$ & - & - & $\begin{array}{c}0.007 \\
(0.026)\end{array}$ & - & - & - \\
\hline $\begin{array}{l}\text { Sustainable } \\
\text { Economic } \\
\text { Opportunity }\end{array}$ & - & - & - & $\begin{array}{l}-0.046 \\
(0.031)\end{array}$ & - & - \\
\hline $\begin{array}{l}\text { Human } \\
\text { Development }\end{array}$ & - & - & - & - & $\begin{array}{l}-0.091^{\star \star \star} \\
(0.030)\end{array}$ & - \\
\hline $\begin{array}{l}\text { Environmental } \\
\text { Governance }\end{array}$ & - & - & - & - & - & $\begin{array}{c}0.895 \\
(0.650)\end{array}$ \\
\hline $\begin{array}{l}\log (G D P) \\
\text { (constant } 2010 \\
\text { US) }\end{array}$ & $\begin{array}{l}0.471^{\star \star} \\
(0.206)\end{array}$ & $\begin{array}{l}0.430 \star \star \\
(0.206)\end{array}$ & $\begin{array}{l}0.415^{\star} \\
(0.206)\end{array}$ & $\begin{array}{l}0.551^{\star \star} \\
(0.217)\end{array}$ & $\begin{array}{l}0.525^{\star \star \star} \\
(0.181)\end{array}$ & $\begin{array}{l}-0.005 \\
(0.180)\end{array}$ \\
\hline $\begin{array}{l}\text { log(Population } \\
\text { Density) }\end{array}$ & $\begin{array}{c}0.315 \\
(0.364)\end{array}$ & $\begin{array}{c}0.151 \\
(0.340)\end{array}$ & $\begin{array}{c}0.032 \\
(0.331)\end{array}$ & $\begin{array}{c}0.376 \\
(0.352)\end{array}$ & $\begin{array}{l}0.801^{\star \star} \\
(0.351)\end{array}$ & $\begin{array}{l}-0.096 \\
(0.266)\end{array}$ \\
\hline $\begin{array}{l}\text { Tree Covered } \\
\text { Area in PAs in } \\
2008(\%)\end{array}$ & $\begin{array}{l}-0.006 \\
(0.010)\end{array}$ & $\begin{array}{l}-0.005 \\
(0.010)\end{array}$ & $\begin{array}{l}-0.004 \\
(0.010)\end{array}$ & $\begin{array}{l}-0.007 \\
(0.010)\end{array}$ & $\begin{array}{l}-0.005 \\
(0.009)\end{array}$ & $\begin{array}{l}-0.017^{*} \\
(0.009)\end{array}$ \\
\hline $\begin{array}{l}\text { Overall }^{\star} \\
\text { Environmental } \\
\text { Governance }\end{array}$ & - & - & - & - & - & $\begin{array}{l}-0.020^{*} \\
(0.010)\end{array}$ \\
\hline Intercept & $\begin{array}{c}-11.691^{\star \star} \\
(5.138)\end{array}$ & $\begin{array}{c}-11.212^{\star \star} \\
(5.233)\end{array}$ & $\begin{array}{c}-11.453^{\star \star} \\
(5.238)\end{array}$ & $\begin{array}{c}-13.574^{\star \star} \\
(5.265)\end{array}$ & $\begin{array}{c}-12.233^{\star \star} \\
(4.550)\end{array}$ & $\begin{array}{l}-5.618 \\
(4.891)\end{array}$ \\
\hline Observations & 33 & 33 & 33 & 33 & 33 & 26 \\
\hline$R^{2}$ & 0.183 & 0.155 & 0.151 & 0.209 & 0.360 & 0.409 \\
\hline Adjusted $R^{2}$ & 0.067 & 0.034 & 0.030 & 0.096 & 0.269 & 0.222 \\
\hline $\begin{array}{l}\text { Residual } \\
\text { Standard Error }\end{array}$ & $\begin{array}{c}1.807 \\
(\mathrm{df}=28)\end{array}$ & $\begin{array}{c}1.838 \\
(\mathrm{df}=28)\end{array}$ & $\begin{array}{c}1.842 \\
(\mathrm{df}=28)\end{array}$ & $\begin{array}{c}1.778 \\
(\mathrm{df}=28)\end{array}$ & $\begin{array}{c}1.599 \\
(\mathrm{df}=28)\end{array}$ & $\begin{array}{c}1.121 \\
(\mathrm{df}=19)\end{array}$ \\
\hline F Statistic & $\begin{array}{c}1.571 \\
(\mathrm{df}= \\
4 ; 28)\end{array}$ & $\begin{array}{c}1.281 \\
(\mathrm{df}= \\
4 ; 28)\end{array}$ & $\begin{array}{c}1.243 \\
(\mathrm{df}= \\
4 ; 28)\end{array}$ & $\begin{array}{c}1.852 \\
(\mathrm{df}= \\
4 ; 28)\end{array}$ & $\begin{array}{c}3.941^{\star \star} \\
(\mathrm{df}= \\
4 ; 28)\end{array}$ & $\begin{array}{c}2.192^{\star} \\
(\mathrm{df}= \\
6 ; 19)\end{array}$ \\
\hline
\end{tabular}

Each column (1) to (6) represents a separate model. A dash indicates the variable was not included in the model.

${ }^{*} p<0.1 ;{ }^{* *} p<0.05 ;{ }^{* * *} p<0.01$.

in the amount of tree cover in PAs across the countries (see Supplementary Table $\mathbf{1}$ for a description of all variables and descriptive statistics).

Thirdly, to explore the role of environmental governance in counteracting possible negative effects of better quality in overall governance, we tested for the interaction term of 'Overall Governance' with 'Environmental Governance,' both across and within countries [models (6) in Tables 1, 2].

panel data for the time period of our analysis and the years in which it was available for single countries varied considerably.
TABLE 2 | Summary of parameter estimates (clustered SE) from panel linear regression of tree cover loss against governance and additional covariates, considering changes within countries over time.

\begin{tabular}{|c|c|c|c|c|c|c|}
\hline & \multicolumn{6}{|c|}{ Dependent variable: } \\
\hline & \multicolumn{6}{|c|}{ Annual tree cover loss rate in PAs $(\%$, log transformed) } \\
\hline & (1) & (2) & (3) & (4) & (5) & $(6)$ \\
\hline $\begin{array}{l}\text { Overall } \\
\text { Governance }\end{array}$ & $\begin{array}{c}0.084 \\
(0.059)\end{array}$ & - & - & - & - & $\begin{array}{c}0.060 \\
(0.071)\end{array}$ \\
\hline $\begin{array}{l}\text { Safety and Rule } \\
\text { of Law }\end{array}$ & - & $\begin{array}{c}0.046 \\
(0.030)\end{array}$ & - & - & - & - \\
\hline $\begin{array}{l}\text { Participation } \\
\text { and Human } \\
\text { Rights }\end{array}$ & - & - & $\begin{array}{l}-0.002 \\
(0.020)\end{array}$ & - & - & - \\
\hline $\begin{array}{l}\text { Sustainable } \\
\text { Economic } \\
\text { Opportunity }\end{array}$ & - & - & - & $\begin{array}{c}0.032 \\
(0.036)\end{array}$ & - & - \\
\hline $\begin{array}{l}\text { Human } \\
\text { Development }\end{array}$ & - & - & - & - & $\begin{array}{c}0.052 \\
(0.045)\end{array}$ & - \\
\hline $\begin{array}{l}\text { Environmental } \\
\text { Governance }\end{array}$ & - & - & - & - & - & $\begin{array}{c}0.327 \\
(0.528)\end{array}$ \\
\hline $\begin{array}{l}\log (\mathrm{GDP}) \\
\text { (constant } 2010 \\
\text { US) }\end{array}$ & $\begin{array}{l}-0.952 \\
(0.923)\end{array}$ & $\begin{array}{l}-0.836 \\
(0.794)\end{array}$ & $\begin{array}{l}-0.176 \\
(0.514)\end{array}$ & $\begin{array}{l}-0.466 \\
(0.696)\end{array}$ & $\begin{array}{l}-0.646 \\
(0.836)\end{array}$ & $\begin{array}{l}-0.716 \\
(1.121)\end{array}$ \\
\hline $\begin{array}{l}\text { log(Population } \\
\text { Density) }\end{array}$ & $\begin{array}{c}0.793 \\
(4.596)\end{array}$ & $\begin{array}{c}0.911 \\
(4.698)\end{array}$ & $\begin{array}{c}0.581 \\
(4.790)\end{array}$ & $\begin{array}{c}0.818 \\
(4.804)\end{array}$ & $\begin{array}{c}0.102 \\
(4.238)\end{array}$ & $\begin{array}{c}5.656 \\
(7.757)\end{array}$ \\
\hline $\begin{array}{l}\text { Overall*}^{\star} \\
\text { Environmental } \\
\text { Governance }\end{array}$ & - & - & - & - & - & $\begin{array}{l}-0.006 \\
(0.012)\end{array}$ \\
\hline Observations & 325 & 325 & 325 & 325 & 325 & 255 \\
\hline$R^{2}$ & 0.021 & 0.027 & 0.001 & 0.006 & 0.015 & 0.027 \\
\hline Adjusted $R^{2}$ & -0.133 & -0.126 & -0.157 & -0.150 & -0.140 & -0.150 \\
\hline F Statistic & $\begin{array}{c}2.029 \\
(\mathrm{df}=3 \\
280)\end{array}$ & $\begin{array}{c}2.579 * \\
(d f=3 \\
280)\end{array}$ & $\begin{array}{c}0.048 \\
(d f=3 \\
280)\end{array}$ & $\begin{array}{c}0.541 \\
(\mathrm{df}=3 \\
280)\end{array}$ & $\begin{array}{c}1.379 \\
(d f=3 \\
280)\end{array}$ & $\begin{array}{c}1.183 \\
(d f=5 \\
215)\end{array}$ \\
\hline
\end{tabular}

Models include country and time fixed effects. Each column (1) to (6) represents a separate model. A dash indicates the variable was not included in the model. ${ }^{*} p<0.1 ;{ }^{* *} p<0.05 ;{ }^{* * *} p<0.01$.

\section{RESULTS}

All of the countries in our sample apart from Seychelles and São Tomé Príncipe experienced some level of tree cover loss within their PAs (Figure 2). In absolute terms, the largest areas of tree cover were lost in PAs in the Democratic Republic of Congo $\left(5282 \mathrm{~km}^{2}\right)$, Côte d'Ivoire $\left(3343 \mathrm{~km}^{2}\right)$, and Mozambique $\left(1932 \mathrm{~km}^{2}\right)$. However, in percentage terms, smaller countries such as Benin (2.50\%), Sierra Leone (1.95\%), and Malawi (1.81\%) experienced the highest average annual rates of tree cover loss in their PAs. Yet, although tree cover was lost in close to all countries' PAs, the distribution of the annual loss rate is highly skewed: with a mean of $0.56 \%, 20$ of the 33 the countries had a tree cover loss rate below $0.5 \%, 8$ between 0.5 and $1 \%, 4$ between 1 and 2\% and only Benin above 2\% (see Supplementary Figure 1 for a histogram).

The quality of country-level governance was close to normally distributed across all IIAG indicators in the countries included in this study. The scores across the four IIAG 

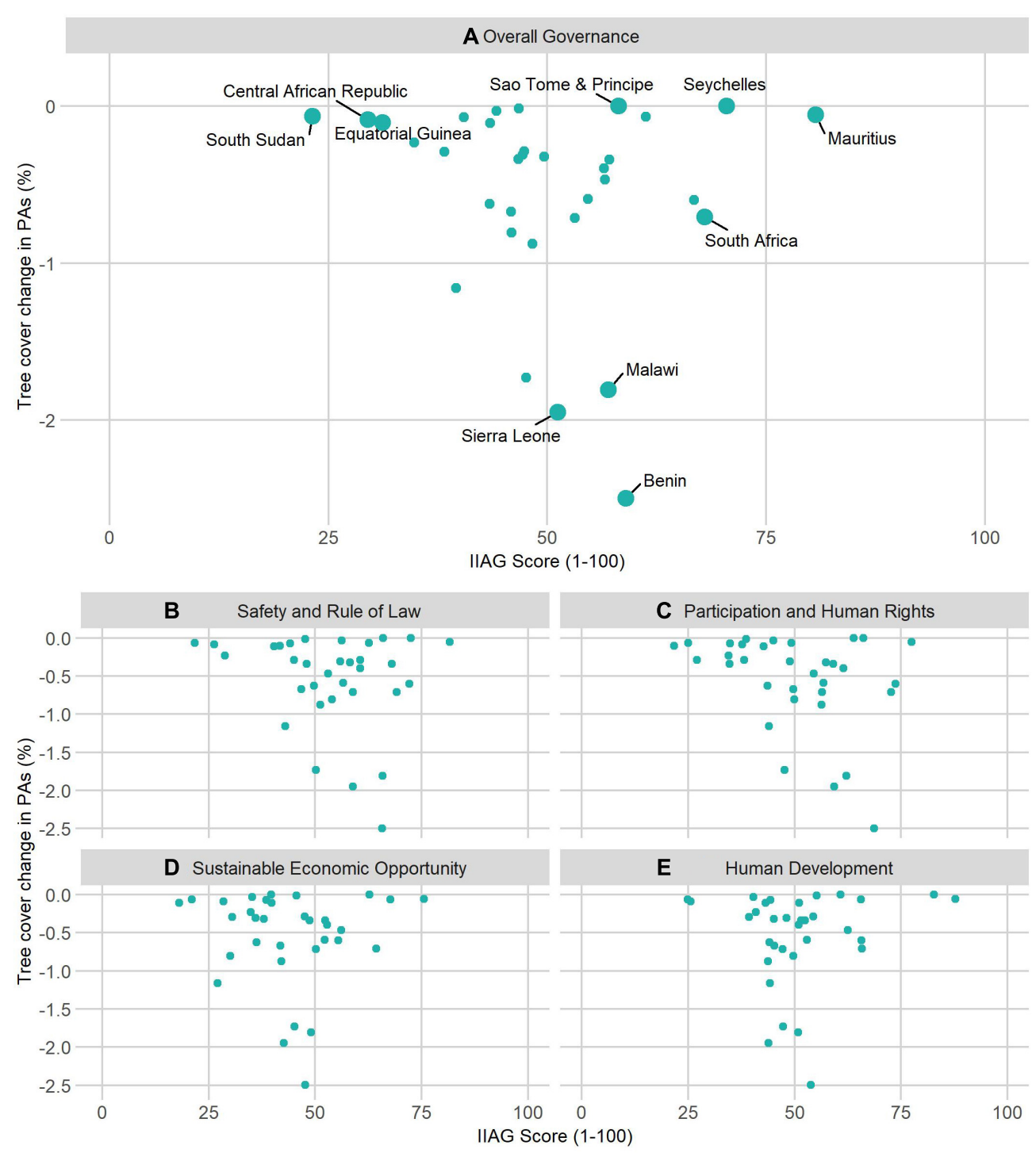

FIGURE 2 | Mean annual rates of tree cover change in PAs plotted against the mean IIAG governance scores for (A) Overall Governance, (B) Safety and Rule of Law, (C) Participation and Human Rights, (D) Sustainable Economic Opportunity, and (E) Human Development for the period 2008-2017. Each point represents one country and countries mentioned in the text are highlighted and labeled.

governance categories are highly correlated across countries and within countries over time (see Supplementary Tables 2,3 for correlation matrices). The three countries with on average highest 'Overall Governance' scores were Mauritius (80.66), Seychelles (70.48), and South Africa (68.00), and with the lowest scores Equatorial Guinea (31.19), Central African Republic (29.50), and South Sudan (23.18) (Figure 2).

Figure 2 plots the mean annual rates of tree cover loss in PAs against the mean scores for governance for each country, visualizing the comparison across countries. The similar pattern across all graphs confirms that the governance indicators correlate and therefore share a similar association with tree cover loss in PAs. The triangular distribution of points in all graphs shows that the severity of tree cover loss varied greatly for countries at the middle range of the governance scores. Countries at the lower and higher ends in the quality of governance all experienced comparatively low rates of tree cover loss in their PAs.

We did not detect a significant relationship between tree cover loss and the individual governance scores apart from 'Human Development' [models (1)-(5) in Table 1]. The 'Human Development' score was significantly negatively correlated with the rate of tree cover loss in PAs, with tree cover loss in PAs decreasing with an increase in welfare, education, and health. There was also a significant positive correlation between GDP and tree cover loss rates in countries' PAs.

We did detect a significant effect for 'Overall Governance' when introducing the interaction term with 'Environmental Governance' to the linear model [model (6) in Table 1]. This indicates that overall and environmental governance combined 
affect rates of tree cover loss. The parameter estimates suggest that tree cover loss in PAs was significantly greater in countries with better overall governance, but that good environmental governance can mediate this relationship. Better environmental governance can partially, though not completely, reduce the negative association between overall governance and tree cover loss in PAs. Yet, where environmental governance scores are low, the negative implications of better overall governance for forests in PAs are estimated to increase.

The panel linear models to analyze whether tree cover loss in PAs was correlated with changes in country-level governance within countries over time did not detect any significant results (Table 2). We cannot predict whether, as a net effect, improvements in country-level governance within a country can be associated with increased or reduced rates of tree cover loss in its PAs.

\section{DISCUSSION}

\section{Tree Cover Loss and Governance}

We undertook a novel analysis to determine if tree cover loss within PAs in sub-Saharan Africa is related to national governance. We were able to look across countries and within countries over time. While tree cover loss was correlated with overall governance across countries after considering environmental governance, the lack of a strong wider correlation could mean that country-level governance in the conventional terms measured by the IIAG is not overall a strong determinant of tree cover loss in PAs. Other drivers and conditions could be more important, including different aspects of governance and governance at different geographical levels.

Governance does vary between PAs, and our analysis treated all PAs together, irrespective of class of protection. The type and quality of site-level governance may be more important in determining the effectiveness of PAs than governance at higher levels (Andrade and Rhodes, 2012; Ferraro et al., 2013; Macura et al., 2015; Bradshaw and Di Minin, 2019). In a recent extensive systematic review, Dawson et al. (2021) synthesize the findings from 169 publications (of which $36 \%$ were based on case studies from Africa) in regard to how different forms of conservation governance influence ecological and social outcomes. The most positive outcomes could be observed where Indigenous peoples and local communities played a central role in decision-making and held clear tenure rights. Conservation efforts controlled by external actors (e.g., the state, NGOs, private firms, etc.) that undermined local customary institutions more often failed in achieving conservation objectives and brought negative social impacts (Dawson et al., 2021). In Africa, where the dominant sitebased conservation model is still state-controlled PAs (UNEPWCMC, 2021), often operating under military presence for law enforcement (Bluwstein, 2018; Boillat et al., 2018; Lunstrum and Ybarra, 2018; Zanamwe et al., 2018; Domínguez and Luoma, 2020), the lag in effectively implementing the decentralization of natural resource governance and integral recognition of local communities' tenure rights could be the bigger reason for ineffective forest protection (Barrett et al., 2001; Sandbrook et al., 2018; Berkes, 2021).
From a different perspective, if the quality of country-level governance is a weak predictor for PA success, this also means that area-based conservation efforts can be successful and worth supporting despite being located in countries with systemic governance challenges. This would be cause for optimism: addressing governance at the site-level is more feasible than transforming governance systems and cultures at scale (BorriniFeyerabend et al., 2013), especially in contexts of longstanding histories of political instability, deeply corrupted public sectors, or inefficient but path-dependent bureaucratic structures. There is increasing interest and funding made available to assess and work toward improving site-level governance in area-based conservation projects, e.g., as part of the IUCN Green List program (Borrini-Feyerabend et al., 2013; Franks et al., 2018; Bennett et al., 2020; IUCN, 2021; Springer et al., 2021). The participatory site-level governance assessment tools developed by the International Institute for Environment and Development (IIED) and partners and that are being piloted across the world provide a practical and context-sensitive framework to kick off and eventually monitor governance transformations from the bottom-up (Echeverri et al., 2021; International Institute for Environment and Development [IIED], 2021a,b; Schéré et al., 2021).

Importantly, however, whilst local-level and bottom-up movements of improving conservation governance appear crucial, more feasible and promising, they do require favorable higher level legal and policy frameworks, as well as "genuine intent" for power shifting (Barrett et al., 2001; Mudliar, 2020; Dawson et al., 2021, p. 9). Good governance in the context of conservation then does not primarily refer to conventional indicators such as corruption control, law enforcement and security, but more specifically to "clear respect for local rights and institutions, decision-making influence for [Indigenous peoples and local communities], and accountability to adhere to these standards" (Dawson et al., 2021, p. 10; citing Ostrom et al., 1999; Brosius, 2004; Borrini-Feyerabend et al., 2013).

\section{Net Effect of Confounding Pathways}

The lack of a strong correlation between country-level governance and PA level conservation outcomes could indicate there is no relationship or it could be a net effect of many complex confounding pathways through which governance quality at the national level trickles down to conservation effectiveness at the PA level (Barrett et al., 2006; Eklund and Cabeza, 2017). Our research design enabled us only to assess to what extent overall, at an aggregated level, country-level governance can be observed to influence tree cover loss in PAs. The lack of a strong correlation could indicate that multiple factors are in fact operating simultaneously and that in sum their effects cancel each other out. Good governance at the country-level may indeed act as an enabling condition for site-level effectiveness whether through 'leakproof' channels for conservation funding, reduced bribery in cases of illegal encroachment or poaching, or successful implementation of decentralization and community tenure mechanisms (Barrett et al., 2006; Nolte et al., 2013; Miller et al., 2015). At the same time, good governance can also act as an enabler for other sectoral developments like agricultural 
investments that can stand in conflict with conservation (Byerlee et al., 2014; Ceddia et al., 2014).

The lack of any strong correlations could also be attributed to the methods and input data that we used. Consequently, nuanced research designs could be required to disentangle the divergent associations. First, from our current simple correlation analysis, we cannot distinguish between the effect of governance on tree cover loss within and outside PAs. This means that we cannot assess the counterfactual of how much tree cover was saved in contrast to if the areas had not been protected (Adams et al., 2014; Barnes et al., 2017; Eklund and Cabeza, 2017). Establishing counterfactuals for each PA (Ferraro, 2009; Pressey et al., 2017) might enable future research to explore relationships in more detail. We may expect, for example, to find that the amount of 'saved' trees is larger in countries with 'better' governance conditions - despite overall increasing tree cover loss within and outside PAs. Establishing credible PA counterfactuals, however, remains a challenge. The accepted approach is based on matching spatial units (whether single pixels at different resolutions or whole areas) within a PA with a unit outside PAs that is most similar based on a number of relevant characteristics (Ferraro, 2009; Beresford et al., 2013; Geldmann et al., 2019). This, however, is not free from limitations and challenges, most important amongst which is accounting for real-world contextual complexities based on a limited set of available observable covariates (Schleicher et al., 2020).

Second, it would be valuable to identify how the influence of country-level governance on PA effectiveness varies for different PA governance types (Borrini-Feyerabend et al., 2013; Miller et al., 2015; Eklund and Cabeza, 2017; Archibald et al., 2020). We could assume that the channels from the country level to the site level for corrupt practices or inefficient bureaucracies is more direct for state-led PAs in comparison to more locally managed conservation sites. Community-managed PAs may be more independent of higher-level governance practices and therefore less affected. Yet, unfortunately, the number of PAs in Africa for which the WDPA reports governance type is too limited to undertake this analysis. We highly recommend encouraging complete entries in the WDPA. With the increasing research to be expected on the governance and management of PAs in the light of the aspirations to expand the worldwide PA network, complete entries to the WDPA are in high demand (Zafra-Calvo and Geldmann, 2020; Secretariat of the United Nations Convention on Biological Diversity [CBD], 2021).

Third, possible temporal complexities need to be considered, particularly when analyzing within countries how changes in governance, whether steady trends or temporally defined events, can be felt at conservation sites, where some local effects may occur instantaneously, whilst others are only felt after months or years (Eklund and Cabeza, 2017). The importance of governance quality can equally be affected by other temporal factors, such as sudden value gains in commodity prices (Laurance, 2004; Byerlee et al., 2014). We did a first simple attempt at checking for time-lags by conducting the panel linear regression model between governance scores and tree cover loss rates in the following 1-3 years (see results in Supplementary Tables 4-7). However, the results showed no significant relationships. Followup research could be based on case-based analyses of countries that experienced noticeable peaks or drops in their quality scores or levels of tree cover loss.

\section{Importance of Environmental Governance}

Our finding that the quality of overall governance interacts with the strength of environmental governance is in line with previous findings and understandings presented for Latin America by Byerlee et al. (2014) and Ceddia et al. (2014). Although their arguments specifically focus on underlying causes for agricultural expansion into tropical forests in light of intensification, their discussion and findings on the role of governance seem relevant in relation to our finding. Byerlee et al. (2014) discuss that when intensification of agricultural production is driven by new market opportunities, for example because of improved markets and infrastructure (both concepts that are included in the IIAG), raised profitability and returns to land provide incentives to expand agricultural land and lead to deforestation. Strong land and forest governance including land rights, environmental regulation, market certification and payment for ecosystem services are then needed to counteract such market incentives. As outlined earlier, Ceddia et al. (2014) provide empirical evidence for this argumentation for Latin America.

Yet, we observe important limitations in the available data for environmental governance. The indicator we used is a unidimensional score derived from expert valuation as part of a larger expert survey to assess several aspects of country-level governance and policy (Bertelsmann Stiftung, 2020). Although country-experts refer to policies or laws in producing scores, this is a very reductionist approach for a multi-faceted concept, including distinctions not only across different environmental concerns (from biodiversity to climate change, energy transitions and water management), but equally from adaptation to mitigation and policy formulation to implementation. Other indices such as the environmental governance indicators used in Ceddia et al. (2014) are available, but these are based on outcomes, including forest conservation metrics. Thus, there would be circularity in using these indices in our analysis. We therefore highlight the need for a sophisticated measure of environmental governance. This should assess countries' legal and policy frameworks for environmental sustainability and the quality of their implementation. Better data for environmental governance to confidently understand and prove its role in halting biodiversity loss, especially in the face of generally improving governance across the African continent, is crucial to support political willingness of governments, donors and international NGOs to prioritize rapid improvements in environmental governance.

\section{Lack of Relevant and Good Quality Data}

If we want to ensure accountability of the new legal designations and high investments that are expected to be diverted to 
conservation through the CBD's ' 30 by 30 ' target, better data are needed all round (Green et al., 2019; Buchanan et al., 2020). Monitoring the ecological effectiveness of PAs remains a challenge (Adams et al., 2014; Barnes et al., 2017; Geldmann et al., 2020). Lack of geographically and temporally comparable data on biodiversity trends inside and outside PAs strongly limits the validity, reliability and conceptual reach of currently feasible analyses (Eklund and Cabeza, 2017). Monitoring biodiversity trends on the ground is costly and PA managers lack incentives to divert scarce resources to unbiased monitoring and evaluation (Adams et al., 2014; Barnes et al., 2017). This leads to incomplete and often incomparable databases at the global scale (Geldmann et al., 2020). Thus, studies of biodiversity trends have been constrained to use case study analyses (Geldmann et al., 2013), meta-analyses of such (e.g., Geldmann et al., 2013; Oldekop et al., 2016; Jager et al., 2019), or fragmentary databases through efforts of pulling together species population trends from diverse location-specific sources [e.g., the Living Planet Database (LPD), Loh et al., 2005, used e.g., in Barnes et al. (2016) and Geldmann et al. (2018)]. The Global Biodiversity Outlook (Secretariat of the Convention on Biological Diversity [CBD], 2020) does provide a global assessment of progress toward the CBD 'Aichi' targets, and development of SMART indicators for the post 2020 Global Biodiversity Framework will be essential (Green et al., 2019). Yet, the available data on species populations outside PAs is insufficient to robustly assess the difference made through formal protection, let alone other effective conservation measures (Barnes et al., 2016). An alternative approach, as chosen in this study, is to proxy biodiversity trends based on remotely sensed land cover data to capture habitat loss, such as tree cover, land use change or fire incidences (e.g., Nelson and Chomitz, 2011; Beresford et al., 2013; Wade et al., 2020). Although satellite-sensed data such as the Hansen Global Forest Change data have wide geographical and time-series coverage, remotely detected habitat cover does not guarantee biodiversity intactness on the ground (i.e., "empty forests syndrome": Eklund and Cabeza, 2017, p. 30; Geldmann et al., 2018, p. 2). Other studies have used human pressures [e.g., variants of the Human Footprint Index (HFI), used e.g., in Jones et al. (2018), Geldmann et al. (2019), and Zafra-Calvo and Geldmann (2020)] or the quality of PA management as reported through Protected Area Management Effectiveness assessment tools (PAME) (Eklund and Cabeza, 2017) to estimate the effectiveness of PAs. The European Commission's Joint Research Centre is putting great efforts into compiling all available data in the Digital Observatory of Protected Areas (DOPA) to monitor PAs at the global scale (Dubois et al., 2018). Nonetheless, a combination of limited area coverage (in LPD and DOPA), lack of time-series or sufficiently recent data (in LPD, HFI, DOPA), challenges in overcoming the overlapping structure of PAs in the WDPA (in DOPA), and doubts about the validity of PA managers' reports on PA outcomes (in PAME) mean that any study on PA effectiveness is substantially limited. We therefore echo other authors (Adams et al., 2014; Barnes et al., 2016; Eklund and Cabeza, 2017; Pressey et al., 2017; Geldmann et al., 2018, 2019, 2020) in calling for globally standardized and repeated data collection to more accurately monitor trends in biodiversity inside and beyond PAs.
The validity and reliability of available governance measures must also be considered (Gisselquist, 2014; Eklund and Cabeza, 2017). There is, in the first place, an epistemological concern that computing an aggregated quantitative measure of what is qualitatively a very complex concept is too simplistic and that more interpretive approaches are needed for any meaningful analysis (Hyden et al., 2003; Bevir and Rhodes, 2006). Composite measures of governance, whilst useful for cross-country comparisons and the exploration of general trends over time, must be interpreted for decision-making in relation to more close-up analyses of situated processes at the country and sub-country levels (Bevir and Rhodes, 2006; Gisselquist, 2014). Gisselquist (2014), a co-author of the first two editions of the IIAG, developed ten questions to help evaluate the quality of composite governance measures. These relate in the first place to general principles of social science methodology including concept formation and operationalization, data quality, transparency and replicability. The composition of the IIAG is documented in great detail, including its underlying conceptual framework, indicator sources and imputation methods amongst others (Mo Ibrahim Foundation, 2018). Despite building on a diverse range of data sources, the IIAG faces the same data quality and operationalization challenges as other governancerelated metrics. Many components of governance, such as corruption, are extremely difficult to measure, impacting reliability and, when proxied with data that imperfectly matches the underlying concept, the validity of measures. Particularly in sub-Saharan Africa, national statistics can be of poor quality, leading to considerable data incompleteness (Rotberg and Gisselquist, 2009). Overall aggregate governance scores are therefore inevitably imprecise and uncertain (Gisselquist, 2014). The IIAG's limitations in accurately measuring the quality of country-level governance is therefore likely to contribute to the inconclusive outcomes of our study.

Furthermore, while definitions of governance are manifold and contested, the IIAG uses a comparatively broad definition by considering all "the political, social and economic goods and services that every citizen has the right to expect from their state" (Gisselquist, 2014; Mo Ibrahim Foundation, 2018, p. 4). Further analysis could benefit from separately considering lowerlevel indicators to analyze more specific relationships between single components of governance and conservation outcomes. Such an analysis would be especially relevant with indicators that are already known from elsewhere to be important for conservation, such as secure land tenure, local participation, gender equality and other forms of respect for the rights of Indigenous peoples and local communities (Borrini-Feyerabend et al., 2013; Dawson et al., 2021). With the potential for different governance elements to be interrelated, as found at the IIAG sub-indicator level in this study, care is needed in interpreting possible collinearity.

Finally, our conceptual framework and discussion highlighted the importance of paying attention to the quality and equity in PA-level governance arrangements and mechanisms. Tools that assess and help improve site-level governance are emerging (Zafra-Calvo et al., 2017; Franks et al., 2018; Echeverri et al., 2021; International Institute for Environment and Development [IIED], 2021a,b; Springer et al., 2021) and could in the long 
term, if systematically recorded and made publicly available, support meta-analyses (Zafra-Calvo et al., 2019; Zafra-Calvo and Geldmann, 2020). These tools are also important to enable studies that consider not only the ecological but also social impacts of conservation measures at local and regional scales (Andrade and Rhodes, 2012; Miller et al., 2015; Oldekop et al., 2016; Miller and Nakamura, 2018).

\section{CONCLUSION}

This research was a first attempt to empirically explore the significance of country-level governance quality for forest conservation in PAs in sub-Saharan Africa. Most importantly, it showed that overall governance indicators as measured by the IIAG are not a strong predictor for conservation success in terms of rates of tree cover loss in PAs. The relation between 'good governance' and conservation success is more complex than a direct and positive cause and effect. Uncertainty remains about the many possible and likely confounding pathways: whilst the quality of overall governance may be mirrored at the site-level (Smith et al., 2003; Laurance, 2004; Barrett et al., 2006), it may also contribute to increases in anthropogenic pressures (Barrett et al., 2006; Byerlee et al., 2014; Ceddia et al., 2014; Eklund and Cabeza, 2017). It would be of substantial policy relevance to disentangle these indirect relationships to disrupt the negative and support the positive pathways. The likely importance of strong environmental governance - as indicated by our study, but more convincingly shown for Latin America (Byerlee et al., 2014; Ceddia et al., 2014) - is one example. In light of the proposed ' 30 by 30' target, further research is needed, based on more complex research designs, but also supported by better-quality data for environmental governance, PA site-level governance and conservation outcomes, to more robustly assess the role of different aspects of governance in achieving equitable and effective conservation in PAs and beyond.

\section{DATA AVAILABILITY STATEMENT}

Publicly available datasets were analyzed in this study. This data can be found here: Ibrahim Index of African Governance: https:

\section{REFERENCES}

Achard, F., Beuchle, R., Mayaux, P., Stibig, H. J., Bodart, C., Brink, A., et al. (2014). Determination of tropical deforestation rates and related carbon losses from 1990 to 2010. Glob. Chang. Biol. 20, 2540-2554. doi: 10.1111/gcb.12605

Adams, V. M., Game, E. T., and Bode, M. (2014). Synthesis and review: delivering on conservation promises: the challenges of managing and measuring conservation outcomes. Environ. Res. Lett. 9:085002. doi: 10.1088/1748-9326/ 9/8/085002

AfDB (2021). African Economic Outlook. From debt resolution to growth: The road ahead for Africa. Abidjan: AfDB.

Amano, T., Székely, T., Sandel, B., Nagy, S., Mundkur, T., Langendoen, T., et al. (2018). Successful conservation of global waterbird populations depends on effective governance. Nature 553, 199-202. doi: 10.1038/nature2 5139 //iiag.online/downloads.html; Hansen Global Forest Change Dataset: https://earthenginepartners.appspot.com/science-2013global-forest/download_v1.6.html; World Database of Protected Areas: https://www.protectedplanet.net/en/thematic-areas/ wdpa?tab=WDPA; World Development Indicators: https:// databank.worldbank.org/source/world-development-indicators.

\section{AUTHOR CONTRIBUTIONS}

PF conceived of the research idea. ND reviewed the literature and available databases. and drafted the manuscript PF, KS, and ND discussed the research framing, research design options, and the interpretation of results. $\mathrm{AB}$ and $\mathrm{ND}$ conducted the data preparation and analysis. GB substantially guided the analysis and interpretation of results. $\mathrm{PF}, \mathrm{KS}, \mathrm{AB}, \mathrm{GB}$, and TD reviewed and commented on the manuscript. All the authors contributed to the article and approved the submitted version.

\section{FUNDING}

This work was supported by the Economic and Social Research Council [ES/P000703/1].

\section{ACKNOWLEDGMENTS}

We thank Jonas Geldmann, Adam Devenish, Abbie Chapman, Edward Lewis, Arnout van Soesbergen, Neil Burgess, Noelia Zafra-Calvo, Gregoire Dubois, and Stephen Woodley for their guiding insight and advice regarding available databases, research design considerations, data preparation, and/or for reviewing the analysis and results. We also thank the editor and the two reviewers for their useful comments.

\section{SUPPLEMENTARY MATERIAL}

The Supplementary Material for this article can be found online at: https://www.frontiersin.org/articles/10.3389/ffgc.2022. 807214/full\#supplementary-material

Andrade, G. S. M., and Rhodes, J. R. (2012). Protected areas and local communities: an inevitable partnership toward successful conservation strategies?. Ecol. Soc. 17:14. doi: 10.5751/ES-05216-170414

Archibald, C. L., Barnes, M. D., Tulloch, A. I. T., Fitzsimons, J. A., Morrison, T. H., Mills, M., et al. (2020). Differences among protected area governance types matter for conserving vegetation communities at-risk of loss and fragmentation. Biol. Conserv. 247:108533. doi: 10.1016/j.biocon.2020.108533

Auguie, B. (2017). gridExtra: Miscellaneous Functions for "Grid" Graphics ( $R$ package version 2.3). Available online at: https://cran.r-project.org/package= gridExtra (accessed February 2, 2022).

Barnes, M. D., Craigie, I. D., Dudley, N., and Hockings, M. (2017). Understanding local-scale drivers of biodiversity outcomes in terrestrial protected areas. Ann. N. Y. Acad. Sci. 1399, 42-60. doi: 10.1111/nyas.13154

Barnes, M. D., Craigie, I. D., Harrison, L. B., Geldmann, J., Collen, B., Whitmee, S., et al. (2016). Wildlife population trends in protected areas predicted by 
national socio-economic metrics and body size. Nat. Commun. 7:12747 . doi: $10.1038 /$ ncomms 12747

Barrett, C. B., Brandon, K., Gibson, C., and Gjertsen, H. (2001). Conserving Tropical Biodiversity amid Weak Institutions. BioScience 51, 497-502.

Barrett, C. B., Gibson, C. C., Hoffman, B., and McCubbins, M. D. (2006). The complex links between governance and biodiversity. Conserv. Biol. 20, 1358 1366. doi: 10.1111/j.1523-1739.2006.00521.x

Bennett, N. J., Calò, A., Di Franco, A., Niccolini, F., Marzo, D., Domina, I., et al. (2020). Social equity and marine protected areas: perceptions of small-scale fishermen in the Mediterranean Sea. Biol. Conserv. 244:108531. doi: 10.1016/ j.biocon.2020.108531

Beresford, A. E., Donald, P. F., and Buchanan, G. M. (2020). Repeatable and standardised monitoring of threats to Key Biodiversity Areas in Africa using Google Earth Engine. Ecol. Indic. 109:105763. doi: 10.1016/j.ecolind.2019. 105763

Beresford, A. E., Eshiamwata, G. W., Donald, P. F., Balmford, A., Bertzky, B., Brink, A. B., et al. (2013). Protection Reduces Loss of Natural Land-Cover at Sites of Conservation Importance across Africa. PLoS One 8:e65370. doi: 10.1371/journal.pone.0065370

Berkes, F. (2021). Advanced Introduction to Community-based Conservation. Cheltenham: Edward Elgar Publishing.

Bertelsmann Stiftung (2020). Transformation Index of the Bertelsmann Stiftung 2020: Codebook for Country Assessments. Gütersloh: Bertelsmann Stiftung.

Bevir, M. (2012). Governance: A Very Short Introduction. Oxford: Oxford University Press.

Bevir, M., and Rhodes, R. (2006). Governance Stories, Routledge Advances in European Politics. England: Routledge.

Bluwstein, J. (2018). From colonial fortresses to neoliberal landscapes in Northern Tanzania: a biopolitical ecology of wildlife conservation. J. Political Ecol. 25, 144-168. doi: 10.2458/v25i1.22865

Boillat, S., Gerber, J. D., Oberlack, C., Zaehringer, J. G., Speranza, C. I., and Rist, S. (2018). Distant interactions, power, and environmental justice in protected area governance: a telecoupling perspective. Sustainability 10:3954. doi: 10.3390/ su10113954

Bolam, F. C., Mair, L., Angelico, M., Brooks, T. M., Burgman, M., Hermes, C., et al. (2021). How many bird and mammal extinctions has recent conservation action prevented?. Conserv. Lett. 14:e12762. doi: 10.1111/conl.12762

Borrini-Feyerabend, G., Dudley, N., Jaeger, T., Lassen, B., Broome, N. P., Phillips, A., et al. (2013). Governance of Protected Areas: From understanding to action. Developing capacity for a protected planet IUCN WCPA's best practise protected area guidelines series No.20. Available online at: www.iucn.org/pa_guidelines (accessed June 5, 2020).

Bradshaw, C. J. A., and Di Minin, E. (2019). Socio-economic predictors of environmental performance among African nations. Sci. Rep. 9:9306 . doi: 10.1038/s41598-019-45762-3

Brosius, J. P. (2004). Indigenous peoples and protected at the world parks congress. Conserv. Biol. 18, 609-612. doi: 10.1111/j.1523-1739.2004.01834.x

Buchanan, G. M., Butchart, S. H. M., Chandler, G., and Gregory, R. D. (2020). Assessment of national-level progress towards elements of the Aichi Biodiversity Targets. Ecol. Indic. 116:106497. doi: 10.1016/j.ecolind.2020.106497

Burnside, C., and Dollar, D. (2004). Aid, Policies, and Growth: Revisiting the Evidence. In World Bank Policy Research Working Paper (No. 3251). Washington: World Bank. doi: 10.2139/ssrn.610292

Byerlee, D., Stevenson, J., and Villoria, N. (2014). Does intensification slow crop land expansion or encourage deforestation?. Glob. Food Sec. 3, 92-98. doi: 10.1016/j.gfs.2014.04.001

Ceddia, M. G., Bardsley, N. O., Gomez-Y-Paloma, S., and Sedlacek, S. (2014). Governance, agricultural intensification, and land sparing in tropical South America. Proc. Natl. Acad. Sci. U. S. A. 111, 7242-7247. doi: 10.1073/pnas. 1317967111

Ceddia, M. G., Sedlacek, S., Bardsley, N. O., and Gomez-y-Paloma, S. (2013). Sustainable agricultural intensification or Jevons paradox? The role of public governance in tropical South America. Glob. Environ. Chang. 23, 1052-1063. doi: 10.1016/j.gloenvcha.2013.07.005

Croissant, Y., and Millo, G. (2008). Panel data econometrics in R: the plm package. J. Stat. Softw. 27, 1-43. doi: 10.18637/jss.v027.i02
Curtis, P. G., Slay, C. M., Harris, N. L., Tyukavina, A., and Hansen, M. C. (2018). Classifying drivers of global forest loss. Science 361, 1108-1111. doi: 10.1126/ science.aau3445

Dawson, N. M., Coolsaet, B., Sterling, E. J., Loveridge, R., Gross-Camp, N. D., Wongbusarakum, S., et al. (2021). The role of Indigenous peoples and local communities in effective and equitable conservation. Ecol. Soc. 26:19. doi: 10. 5751/es-12625-260319

Deacon, R. T. (1994). Deforestation and the Rule of Law in a Cross-Section of Countries. Land Econ. 70, 414-430. doi: 10.2307/3146638

Domínguez, L., and Luoma, C. (2020). Decolonising conservation policy: how colonial land and conservation ideologies persist and perpetuate indigenous injustices at the expense of the environment. Land 9, 11-14. doi: 10.3390/ land 9030065

Dubois, G., Mandrici, A., Delli, G., Battistella, L., Bastin, L., Garcia Bendito, E., et al. (2018). Digital Observatory for Protected Areas (p. JRC115972). Belgium: European Commission.

Dudley, N. (2008). Guidelines for Applying Protected area Management Categories. Switzerland: IUCN. doi: 10.2305/iucn.ch.2008.paps.2.en

Echeverri, J., Cely-gómez, A., Zafra-calvo, N., González, J., Matallana-tobón, C., Santamaría, M., et al. (2021). Short communication: application of site-level assessment of governance and equity (sage) methodology to a candidate oecm: AndakÍ municipal natural park, caquetÁ, colombia. Parks 27, 85-90. doi: 10. 2305/IUCN.CH.2021.PARKS-27-1JE.en

Eklund, J., and Cabeza, M. (2017). Quality of governance and effectiveness of protected areas: crucial concepts for conservation planning. Ann. N. Y. Acad. Sci. 1399, 27-41. doi: 10.1111/nyas. 13284

Ferraro, P. J. (2009). Counterfactual thinking and impact evaluation in environmental policy. New Dir. Eval. 122, 75-84. doi: 10.1002/ev.297

Ferraro, P. J., Hanauer, M. M., Miteva, D. A., Canavire-Bacarreza, G. J., Pattanayak, S. K., and Sims, K. R. E. (2013). More strictly protected areas are not necessarily more protective: evidence from Bolivia, Costa Rica, Indonesia, and Thailand. Environ. Res. Lett. 8:025011. doi: 10.1088/1748-9326/8/2/025011

Food and Agriculture Organization [FAO] (2020a). Global Forest Resources Assessment 2020: Terms and Definitions. In Forest Resources Assessment Working Paper (No. 188). Rome: Food and Agriculture Organization.

Food and Agriculture Organization [FAO] (2020b). Gobal Forest Resources Assessment 2020: Main Report. Rome: Food and Agriculture Organization. doi: $10.4060 /$ ca9825en

Franks, P., Booker, F., and Roe, D. (2018). Understanding and assessing equity in protected area conservation: a matter of governance, rights, social impacts and human wellbeing (Issue IIED Issue Paper). Available online at: http://pubs.iied.org/14671IIEDwww.iied.org@iiedwww.facebook.com/theIIED (accessed October 29, 2020).

Friedman, R. S., Law, E. A., Bennett, N. J., Ives, C. D., Thorn, J. P. R., and Wilson, K. A. (2018). How just and just how? A systematic review of social equity in conservation research. Environ. Res. Lett. 13:053001. doi: 10.1088/1748-9326/ aabcde

Geist, H. J., and Lambin, E. F. (2002). Proximate causes and underlying driving forces of tropical deforestation. BioScience 52, 143-150.

Geldmann, J., Barnes, M., Coad, L., Craigie, I. D., Hockings, M., and Burgess, N. D. (2013). Effectiveness of terrestrial protected areas in reducing habitat loss and population declines. Biol. Conserv. 161, 230-238. doi: 10.1016/j.biocon.2013.02. 018

Geldmann, J., Coad, L., Barnes, M. D., Craigie, I. D., Woodley, S., Balmford, A., et al. (2018). A global analysis of management capacity and ecological outcomes in terrestrial protected areas. Conserv. Lett. 11:e12434. doi: 10.1111/conl.12434

Geldmann, J., Deguignet, M., Balmford, A., Burgess, N. D., Dudley, N., Hockings, M., et al. (2020). Essential indicators for measuring area-based conservation effectiveness in the post-2020 global biodiversity framework. Conserv. Lett. 14:e12792. doi: $10.1111 /$ conl.12792

Geldmann, J., Manica, A., Burgess, N. D., Coad, L., and Balmford, A. (2019). A global-level assessment of the effectiveness of protected areas at resisting anthropogenic pressures. Proc. Natl. Acad. Sci. U. S. A. 116, 23209-23215. doi: $10.1073 /$ pnas.1908221116

Gisselquist, R. M. (2014). Developing and evaluating governance indexes?: 10 questions. Policy Stud. 35, 513-531. doi: 10.1080/01442872.2014.946484 
Gorelick, N., Hancher, M., Dixon, M., Ilyushchenko, S., Thau, D., and Moore, R. (2017). Google Earth Engine: planetary-scale geospatial analysis for everyone. Remote Sens. Environ. 202, 18-27. doi: 10.1016/j.rse.2017.06.031

Green, E. J., Buchanan, G. M., Butchart, S. H. M., Chandler, G. M., Burgess, N. D., Hill, S. L. L., et al. (2019). Relating characteristics of global biodiversity targets to reported progress. Conserv. Biol. 33, 1360-1369. doi: 10.1111/cobi.13322

Hansen, M. C., Potapov, P. V., Moore, R., Hancher, M., Turubanova, S. A., Tyukavina, A., et al. (2013). High-Resolution Global Maps of 21st-Century Forest Cover Change. Science 342, 850-853. doi: 10.1126/science.1244693

Harrell, F. E. Jr., and Dupont, C. (2021). Hmisc: Harrell Miscellaneous (R package version 4.5-0). Available online at: https://cran.r-project.org/package $=\mathrm{Hmisc}$ (accessed February 2, 2022)

Hlavac, M. (2018). stargazer: Well-Formatted Regression and Summary Statistics Tables ( $R$ package version 5.2.1). Available online at: https://cran.r-project.org/ package $=$ stargazer (accessed February 2, 2022).

Hyden, G., Court, J., and Mease, K. (2003). Making sense of governance: the need for involving local stakeholders. In ODI Discussion paper. London: ODI.

International Institute for Environment and Development [IIED] (2021a). Assessing Governance at Protected and Conserved Areas (GAPA). London: IIED.

International Institute for Environment and Development [IIED] (2021b). Site-level Assessment of Governance and Equity (SAGE). London: IIED. https://www.iied.org/site-level-assessment-governance-equity-sage

International Union for Conservation of Nature [IUCN] (2021). IUCN Green List of Protected and Conserved Areas. Switzerland: IUCN.

International Union for Conservation of Nature [IUCN] (2022). IUCN Red List of Threatened Species. Version 2021-3. Switzerland: IUCN.

Jager, N. W., Newig, J., Challies, E., and Kochskämper, E. (2019). Pathways to implementation: evidence on how participation in environmental governance impacts on environmental outcomes. J. Public Adm. Res. Theory 30, 383-399. doi: 10.1093/jopart/muz034

Jones, K. R., Venter, O., Fuller, R. A., Allan, J. R., Maxwell, S. L., Negret, P. J., et al. (2018). One-third of global protected land is under intense human pressure. Science 360, 788-791. doi: 10.1126/science.a ap9565

Kaufmann, D., Kraay, A., and Mastruzzi, M. (2010). The worldwide governance indicators: methodology and analytical issues. Hague J. Rule Law 3, 220-246. doi: $10.1017 /$ S1876404511200046

Laurance, W. F. (2004). The perils of payoff: corruption as a threat to global biodiversity. Trends Ecol. Evol. 19, 399-401. doi: 10.1016/j.tree.2004.06.001

Loh, J., Green, R. E., Ricketts, T., Lamoreux, J., Jenkins, M., Kapos, V., et al. (2005). The Living Planet Index: using species population time series to track trends in biodiversity. Philos. Trans. R. Soc. B Biol. Sci. 360, 289-295. doi: 10.1098/rstb. 2004.1584

Lunstrum, E., and Ybarra, M. (2018). Deploying Difference?: security Threat Narratives and State Displacement from Protected Areas. Conserv. Soc. 16, 114-124. doi: 10.4103/cs.cs

Macura, B., Secco, L., and Pullin, A. S. (2015). What evidence exists on the impact of governance type on the conservation effectiveness of forest protected areas? Knowledge base and evidence gaps. Environ. Evid. 4:24. doi: 10.1186/s13750015-0051-6

Maxwell, S. L., Cazalis, V., Dudley, N., Hoffmann, M., Rodrigues, A. S. L., Stolton, S., et al. (2020). Area-based conservation in the twenty-first century. Nature 586, 217-227. doi: 10.1038/s41586-020-2773-z

McPherson, M. A., and Nieswiadomy, M. L. (2000). African elephants: the effect of property rights and political stability. Contemp. Econo. Policy 18, 14-26. doi: 10.1111/j.1465-7287.2000.tb00002.x

Miller, D. C., Agrawal, A., and Roberts, J. T. (2013). Biodiversity, Governance, and the Allocation of International Aid for Conservation. Conserv. Lett. 6, 12-20. doi: 10.1111/j.1755-263X.2012.00270.x

Miller, D. C., Minn, M., and Sinsin, B. (2015). The importance of national political context to the impacts of international conservation aid: evidence from the $\mathrm{W}$ National Parks of Benin and Niger. Environ. Res. Lett. 10:115001. doi: 10.1088/ 1748-9326/10/11/115001

Miller, D. C., and Nakamura, K. S. (2018). Protected areas and the sustainable governance of forest resources. Curr. Opin. Environ. Sustain. 32, 96-103. doi: 10.1016/j.cosust.2018.05.024

Mo Ibrahim Foundation. (2018). Ibrahim Index of African Governance: Methodology. London: Mo Ibrahim Foundation.
Mudliar, P. (2020). Polycentric to monocentric governance: power dynamics in Lake Victoria’s fisheries. Environ. Policy Gov. 31, 302-315. doi: 10.1002/eet.1917 Nelson, A., and Chomitz, K. M. (2011). Effectiveness of Strict vs. Multiple Use Protected Areas in Reducing Tropical Forest Fires: a Global Analysis Using Matching Methods. PLoS One 6:e22722. doi: 10.1371/journal.pone.0022722

Nolte, C., Agrawal, A., and Barreto, P. (2013). Setting priorities to avoid deforestation in Amazon protected areas: are we choosing the right indicators?. Environ. Res. Lett. 8:015039. doi: 10.1088/1748-9326/8/1/0 15039

Oldekop, J. A., Holmes, G., Harris, W. E., and Evans, K. L. (2016). A global assessment of the social and conservation outcomes of protected areas. Conserv. Biol. 30, 133-141. doi: 10.1111/cobi.12568

Ostrom, E., Burger, J., Field, C. B., Norgaard, R. B., and Policansky, D. (1999). Revisiting the commons: local lessons, global challenges. Science 284, 278-282. doi: 10.1126/science.284.5412.278

Pressey, R. L., Weeks, R., and Gurney, G. G. (2017). From displacement activities to evidence-informed decisions in conservation. Biol. Conserv. 212, 337-348. doi: 10.1016/j.biocon.2017.06.009

QGIS Development Team (2021). QGIS Geographic Information System. Chicago: Open Source Geospatial Foundation Project.

Rotberg, R. I., and Gisselquist, R. M. (2009). Strengthening African Governance Index of African Governance: Results and Rankings 2009. Cambridge: Harvard University.

RStudio Team (2021). RStudio: Integrated Development for $R$ (Version 1.4.1106). Available online at: http://www.rstudio.com/ (accessed February 2, 2022).

Sandbrook, C., Cavanagh, C. J., and Tumusiime, D. M. (2018). "Conservation and Development in Uganda," in Conservation and Development in Cambodia (Earthscan), ed. A. W. M. Bill (Oxfordshire: Routledge), doi: 10.4324/ 9781315887302

Schéré, C. M., Schreckenberg, K., Dawson, T. P., and Jones, N. (2021). It's Just Conservation: to What Extent Are Marine Protected Areas in the Irish Sea Equitably Governed and Managed?. Front. Mar. Sci. 8:668919. doi: 10.3389/ fmars.2021.668919

Schleicher, J., Eklund, J., Barnes, D. M., Geldmann, J., Oldekop, J. A., and Jones, J. P. G. (2020). Statistical matching for conservation science. Conserv. Biol. 34, 538-549. doi: 10.1111/cobi. 13448

Schreckenberg, K., Franks, P., Martin, A., and Lang, B. (2016). Unpacking equity for protected area conservation. Parks 22, 11-26. doi: 10.2305/IUCN.CH.2016. PARKS-22-2KS.en

Secretariat of the Convention on Biological Diversity [CBD] (2020). Global Biodiversity Outlook 5. Available online at: https://www.cbd.int/gbo5 (accessed February 2, 2022).

Secretariat of the United Nations Convention on Biological Diversity [CBD] (2021). First Draft of the Post-2020 Global Biodiversity Framework. In Cbd/Wg2020/3/3. Available online at: https://www.cbd.int/article/draft-1global-biodiversity-framework (accessed October 13, 2021).

Sikor, T., Martin, A., Fisher, J., and He, J. (2014). Toward an Empirical Analysis of Justice in Ecosystem Governance. Conserv. Lett. 7, 524-532. doi: 10.1111/conl. 12142

Slowikowski, K. (2021). ggrepel: Automatically Position Non-Overlapping Text Labels with "ggplot2" (R package version 0.9 .1 ). Available online at: https://cran. r-project.org/package=ggrepel (accessed February 2, 2022).

Smith, R. J., Muir, R. D. J., Walpole, M. J., Balmford, A., and Leader-Williams, N. (2003). Governance and the loss of biodiversity. Nature 426, 67-70. doi: $10.1038 /$ nature02095.1

Springer, J., Campese, J., and Nakangu, B. (2021). The Natural Resource Governance Framework?: improving governance for equitable and effective conservation. Switzerland: IUCN. doi: 10.2305/iucn.ch.20 21.16.en

Svensson, J. (1999). Aid, growth and democracy. Econ. Politics 11, 275-297. doi: $10.1111 / 1468-0343.00062$

UNEP-WCMC (2019). User Manual for the World Database on Protected Areas and world database on other effective area- based conservation measures?: 1.6. Cambridge: UNEP-WCMC.

UNEP-WCMC (2021). Protected Area Profile for Africa from the World Database of Protected Areas. Protected Planet. Cambridge: UNEP-WCMC.

UNESCAP (2009). What is Good Governance? Bangkok: UNESCAP. doi: 10.18356/ d4072237-en-fr (accessed October 14, 2021). 
United Nations (2015). World population prospects: The 2015 revision, key findings and advance tables (ESA/P/WP.241). New York: United Nations.

Usman Mirza, M., Richter, A., van Nes, E. H., and Scheffer, M. (2020). Institutions and inequality interplay shapes the impact of economic growth on biodiversity loss. Ecol. Soc. 25:39. doi: 10.5751/ES-12078-250439

Wade, C. M., Austin, K. G., Cajka, J., Lapidus, D., Everett, K. H., Galperin, D., et al. (2020). What is threatening forests in protected areas? A global assessment of deforestation in protected areas, 2001-2018. Forests 11:539. doi: 10.3390/ F11050539

Wickham, H., Averick, M., Bryan, J., Chang, W., McGowan, L., François, R., et al. (2019). Welcome to the Tidyverse. J. Open Source Softw. 4:1686. doi: 10.21105/ joss. 01686

Wolf, C., Levi, T., Ripple, W. J., Zárrate-Charry, D. A., and Betts, M. G. (2021). A forest loss report card for the world's protected areas. Nat. Ecol. Evol. 5, 520-529. doi: 10.1038/s41559-021-01389-0

World Bank Group (2021). World Development Indicators | DataBank. Washington: Worldbank. https://databank.worldbank.org/source/worlddevelopment-indicators.

Worldbank (2019). WGI 2020 Interactive Data Access. Available online at: http: //info.worldbank.org/governance/wgi/Home/Reports (accessed October 14, 2021).

Zafra-Calvo, N., Garmendia, E., Pascual, U., Palomo, I., Gross-Camp, N., Brockington, D., et al. (2019). Progress toward Equitably Managed Protected Areas in Aichi Target 11: a Global Survey. BioScience 69, 191-197. doi: 10.1093/ biosci/biy143

Zafra-Calvo, N., and Geldmann, J. (2020). Protected areas to deliver biodiversity need management effectiveness and equity. Glob. Ecol. Conserv. 22:e01026. doi: 10.1016/j.gecco.2020.e01026
Zafra-Calvo, N., Pascual, U., Brockington, D., Coolsaet, B., Cortes-Vazquez, J. A., Gross-Camp, N., et al. (2017). Towards an indicator system to assess equitable management in protected areas. Biol. Conserv. 211, 134-141. doi: 10.1016/j. biocon.2017.05.014

Zanamwe, C., Gandiwa, E., Muboko, N., Kupika, O. L., and Mukamuri, B. B. (2018). Ecotourism and wildlife conservation-related enterprise development by local communities within Southern Africa: perspectives from the greater Limpopo Transfrontier Conservation, South-Eastern Lowveld, Zimbabwe. Cogent Environ. Sci. 4:1531463. doi: 10.1080/23311843.2018.1 531463

Conflict of Interest: The authors declare that the research was conducted in the absence of any commercial or financial relationships that could be construed as a potential conflict of interest.

Publisher's Note: All claims expressed in this article are solely those of the authors and do not necessarily represent those of their affiliated organizations, or those of the publisher, the editors and the reviewers. Any product that may be evaluated in this article, or claim that may be made by its manufacturer, is not guaranteed or endorsed by the publisher.

Copyright (c) 2022 Dehmel, Franks, Schreckenberg, Beresford, Buchanan and Dawson. This is an open-access article distributed under the terms of the Creative Commons Attribution License (CC BY). The use, distribution or reproduction in other forums is permitted, provided the original author(s) and the copyright owner(s) are credited and that the original publication in this journal is cited, in accordance with accepted academic practice. No use, distribution or reproduction is permitted which does not comply with these terms. 